\title{
Kesesuaian dan Arahan Penggunaan Lahan Berdasarkan Rencana Pola Ruang Wilayah di Hulu Daerah Aliran Sungai Kelara
}

\author{
Usman Arsyad ${ }^{1, *}$, Andang Suryana Soma ${ }^{1}$, Wahyuni ${ }^{1}$, Tita Rahayu Arief $^{2}$ \\ ${ }^{1}$ Staf Pengajar Fakultas Kehutanan, Universitas Hasanuddin, Makassar, \\ *Email: usman.arsyad@yahoo.co.id, Nomor Telepon: 081242279420 \\ 2Mahasiswa S2 Program Studi Ilmu Kehutanan, Universitas Hasanuddin, Makassar
}

\begin{abstract}
This study aimed to analyze the suitability of land cover with spatial pattern plan and determine the direction of land use in the event of a discrepancy. This research was conducted on the Kelara Upstream Watershed by using land cover maps generated from landsat imagery interpretation 8 . Then overlay to map the spatial pattern plan. Then determined the order of land use is done when there is a discrepancy between the results of the overlay with maps of land cover spatial pattern plan. The result showed that $41,05 \%$ of the total area of the Kelara Upstream Watershed of 28.185,68 ha a land use form of a orchards. After overlay discovered discrepancy land cover maps with maps of spatial pattern plan. Based on a map spatial pattern plan that should in reality the field is man made forest, orchards, dryland agriculture and rice field. According to these conditions the specified order of land use that is $\mathrm{Hkm}$ (Community Forest) with agroforestry and Agroforestry Systems. Rice field In the Protected and Production forest order to intensification land use and plantations forest, orchards and dry land agriculture order to Community Forest with agroforestry systems. In the area of cultivation, the land use rice field, orchards and dryland agriculture order to agroforestry systems.
\end{abstract}

Keywords: Land use; Spatial Pattern Plan; Watershed DOI: http://dx.doi.org/10.24259/jhm.v9i2.2872

\section{PENDAHULUAN}

Kemajuan pembangunan, pertambahan jumlah penduduk dan meningkatnya kebutuhan manusia merupakan kejadian saling terkait. Pesatnya pembangunan untuk menunjang berbagai kebutuhan hidup manusia semakin membutuhkan lahan sehingga semakin mempersempit lahan usaha tani. Zamroh (2014) mengatakan bahwa kemajuan pembangunan di suatu wilayah sejalan dengan peningkatan jumlah pertumbuhan penduduk yang diiringi meningkatnya kualitas dan kuantitas kebutuhan hidup. Hal ini berdampak kepada terjadinya perubahan tata guna lahan yang sulit dikendalikan (Syaifuddin dan Anwar, 2008). Akibatnya, perubahan tata guna lahan tidak sesuai lagi dengan pola ruang yang telah disepakati. Hal seperti ini terjadi pada hampir semua daerah terutama di tingkat kabupaten (As-syakur dan Adnyana, 2009). Apabila keadaan ini dibiarkan berlangsung terus menerus maka dapat dipastikan bahwa luas lahan kritis akan semakin bertambah, erosi dan banjir akan sering terjadi yang berakibat menurunnya daya dukung Daerah Aliran Sungai (Ferdinan, dkk, 2013 dan Zamroh, 2014).

Menurunnya daya dukung DAS dicirikan oleh terjadinya erosi dan sedimentasi, banjir pada musim hujan dan kekeringan pada musim kemarau serta menurunnya produktifitas lahan. Kejadian seperti ini terjadi hampir di seluruh wilayah DAS dari hulu sampai hilir (Menhut, 2014). Menurunnya produktifitas lahan akan menurunkan luasan lahan yang subur dan mengakibatkan terjadinya lahan kritis (Pradana, dkk, 2013). Lahan ini mengalami kerusakan secara fisik, kimia, dan biologis atau lahan yang tidak mempunyai nilai ekonomis lagi. Kejadian seperti ini menunjukkan terjadinya penurunan kemampuan tanah.

Hulu DAS Kelara dengan luas $28.185,69$ ha terletak di dua kabupaten yaitu Kabupaten Gowa dan Kabupaten Jeneponto terdapat penggunaan lahan yang tidak sesuai dengan pola ruang yang sudah ditetapkan. Pada kawasan lindung yang semestinya hutan lindung tetapi ditemukan pemanfaatan lahan berupa perkebunan. Jika terjadi kerusakan akibat konversi lahan yang tidak sesuai RTRW Kabupaten di Hulu DAS Kelara maka akan berdampak ke daerah dibawahnya yaitu di daerah hilir DAS.

Lokasi studi terletak di Hulu DAS Kelara yang merupakan daerah dengan topografi yang curam sampai sangat curam. Pola penggunaan lahan saat ini berupa hutan lahan kering sekunder, hutan 
tanaman, pemukiman, perkebunan, pertanian lahan kering, sawah dan tubuh air. Dari hasil analisis citra dan pengecekan lapangan diketahui bahwa penggunaan lahan terbesar adalah perkebunan. Berdasarkan kondisi fisik wilayah maka diduga telah terjadi ketidaksesuaian penggunaan lahan dengan pola ruang wilayah sehingga perlu dilakukan arahan penggunaan lahan yang sesuai.

Berdasarkan uraian tersebut maka diperlukan suatu penelitian mengenai kesesuaian peta penutupan lahan dengan pola ruang wilayah, sehingga akan diperoleh suatu informasi akurat yang dapat di pertimbangkan kedepannya. Untuk itu dilakukan penelitian tentang "Kesesuaian dan Arahan Penutupan Lahan berdasarkan Pola Ruang Wilayah di Hulu Daerah Aliran Sungai Kelara".

\section{METODE PENELITIAN}

Penelitian ini dilaksanakan selama tiga bulan yang dimulai pada awal bulan Mei sampai dengan akhir bulan Juli 2015 melalui dua tahapan, yaitu kegiatan lapangan dan analisis data. Kegiatan lapangan dilakukan di Hulu Daerah Aliran Sungai Kelara sedangkan untuk analisis data dilakukan di Laboratorium Perencanaan dan Sistem Informasi Kehutanan dan Pengelolaan Daerah Aliran Sungai Fakultas Kehutanan Universitas Hasanuddin. Peta lokasi penelitian berdasarkan administrasi kecamatan disajikan pada Gambar 1.

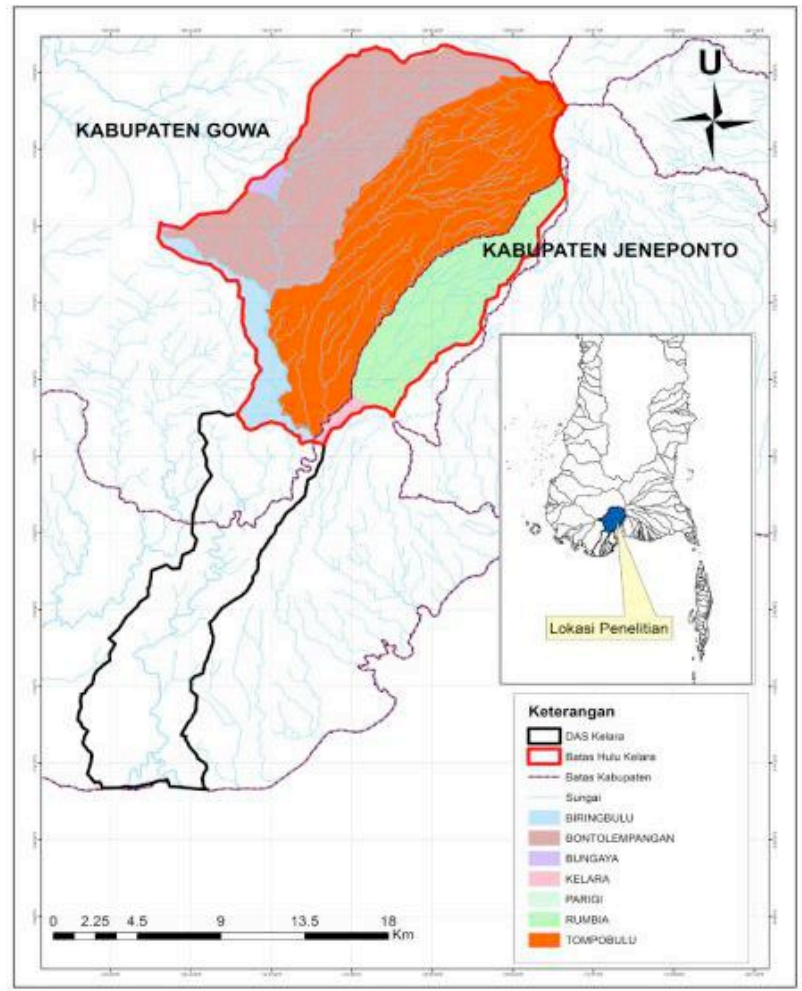

Gambar 1. Peta Lokasi Penelitian

\subsection{Teknik Pengambilan Data}

Data lapangan yang dikumpulkan adalah data fisik dan data sosial. Data fisik dikumpulkan berupa hasil uji akurasi hasil interpretasi dengan kenyataan dilapangan sedangkan data sosial diperoleh dengan teknik Snowball Sampling. Data fisik yang dibutuhkan adalah data titik koordinat yang tidak berkesesuaian antara peta penutupan lahan dengan peta pola ruang. Data sosial yang dibutuhkan adalah sosialisasi dan pemahaman masyarakat tentang pola ruang. Kegiatan wawancara dimulai pada tokoh kunci dan diakhiri setelah tokoh masyarakat memberikan jawaban yang relative sama. Snowball Sampling adalah teknik pengambilan sampel yang mula-mula jumlahnya kecil, kemudian sampel tersebut dicari (digali) keterangan mengenai sampel-sampel lain sehingga jumlah sampel semakin banyak (Udkhiyah, 2013). 


\subsection{Analisis Data}

\section{a. Lokasi Penelitian}

Batas Daerah Aliran Sungai Kelara di dapatkan dari batas DAS Indonesia yang dikeluarkan oleh Balai Pengelolaan Daerah Aliran Sungai Jeneberang-Walanae. Dalam penelitian ini DAS Kelara dibagi menjadi hulu dan hilir. Hulu DAS Kelara yaitu wilayah mulai dari bendungan kelara-karalloe ke arah hulu sedangkan wilayah hilirnya mulai dari bendungan ke arah hilir. Penelitian ini hanya fokus pada daerah hulu DAS Kelara.

\section{b. Interpretasi Citra}

Peta penutupan lahan yang dibuat berasal dari data citra satelit. Citra satelit yang digunakan yaitu citra landsat 8 Path 114 dan Row 64 yang download pada bulan Oktober tahun 2014. Citra tersebut diunduh melalui website http://earthexplorer.usgs.gov. Kemudian, dilakukan interpretasi yang diawali dengan penggabungan band (composite band). Selanjutnya, dilakukan digitasi dengan menggunakan metode digitasi on screen, yaitu mendigitasi langsung citra tersebut secara visual. Kelas penutupan lahan ditetapkan berdasarkan klasifikasi penutupan lahan pola dan karakteristik (rona, warna dan tekstur) pada citra tersebut.

Untuk menguji keakuratan interpretasi citra maka dilakukan uji akurasi klasifikasi citra yang bertujuan untuk mengetahui sejauh mana keakuratan interpretasi citra yang telah dilakukan. Salah satu metode perhitungan tingkat akurasi adalah overall accuracy dengan persamaan sebagai berikut:

$$
\mathrm{OA}=\frac{X}{N} X 100 \%
$$

Dimana: $\quad X=$ jumlah nilai diagonal matriks

$\mathrm{N}=$ jumlah sampel matriks

Tabel 1. Confusion matriks untuk menguji keakuratan interpretasi citra

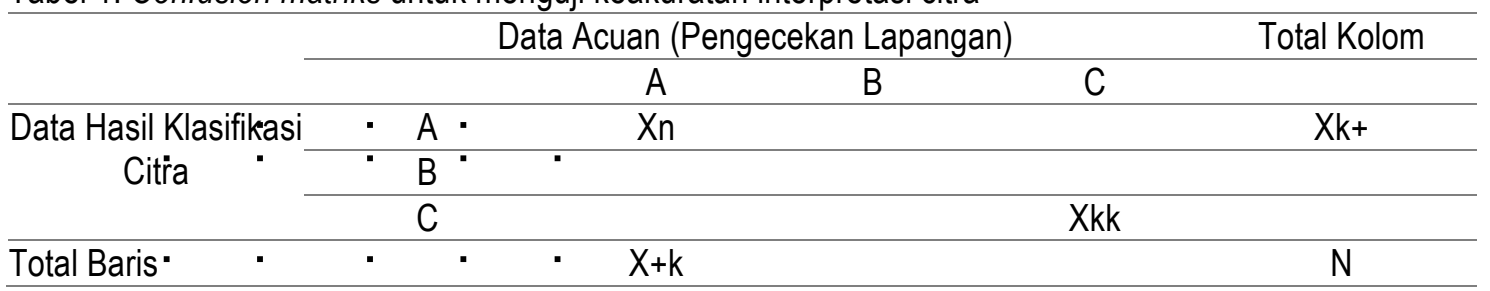

Tingkat keakuratan interpretasi citra yang dapat diterima yaitu $\geq 85 \%$ (Lillesand and kiefer, 1997). Hal ini dapat diartikan bahwa dari 100 titik terdapat 85 titik yang telah ditetapkan harus sesuai dengan keadaan lapangan.

\section{c. Penentuan Kesesuaian}

Penentuan kesesuaian penutupan lahan berdasarkan pola ruang terlebih dahulu melakukan overlay (tumpang susun) terhadap peta penutupan lahan dengan peta pola ruang. Setelah melakukan overlay, penentuan kesesuaian penutupan lahan didasarkan pada hutan menurut fungsinya.

Hutan adalah suatu kesatuan ekosistem berupa hamparan lahan berisi sumber daya alam hayati yang didominasi pepohonan dalam persekutuan alam lingkunganya, yang satu dengan lainnya tidak dapat dipisahkan (Undang-Undang Tentang Kehutanan No.41 tahun 1999). Lebih lanjut diuraikan bahwa hutan mempunyai tiga fungsi yaitu :

1. Fungsi konservasi yaitu hutan konservasi.

2. Fungsi lindung yaitu hutan Lindung.

3. Fungsi produksi yaitu hutan produksi. 


\section{d. Penetapan Koordinat Titik-Titik Pewakil Setiap Penutupan Lahan}

Penetapan koordinat titik-titik yang menjadi pewakil setiap penutupan lahan dilakukan melalui penandaan pada hasil overlay (tumpang susun) peta penutupan lahan dengan peta pola ruang dengan mempertimbangkan faktor kemudahan aksesibilitas dari setiap penutupan lahan yang dipilih. Titik sampel yang telah ditentukan, dicatat dan dimasukkan data koordinatnya ke dalam GPS untuk kemudian dilakukan pengecekan (ground check) dilapangan.

\section{e. Pemeriksaan Lapangan (Ground Check)}

Pengecekan lapangan bertujuan untuk melakukan koreksi terhadap hasil klasifikasi penggunaan lahan tahun 2014. Kegiatan yang dilakukan meliputi pengecekan titik-titik pengamatan sebanyak 43 titik untuk data fisik dan dokumentasi penggunaan lahan yang ada serta dilakukan wawancara terhadap 20 responden untuk data sosial.

\section{f. Perencanaan Arahan Penggunaan Lahan}

Perencanaan Arahan penggunaan lahan dilakukan pada Hulu DAS Kelara yang diarahkan pada Hutan Lindung, Hutan Produksi dan Hutan Konservasi. Pada Kawasan Hutan Lindung dan Kawasan Hutan Produksi diarahkan untuk Hutan Kemasyarakatan $(\mathrm{HKm})$ dengan system agroforestry dan Kawasan Budidaya diarahkan untuk melakukan system agroforestry.

\section{HASIL DAN PEMBAHASAN}

\subsection{Klasifikasi Penggunaan Lahan}

\section{a. Penggunaan lahan}

Hasil interpretasi citra satelit landsat 8 tahun 2014 serta hasil observasi lapangan diketahui bahwa penggunaan lahan berupa kebun pada Hulu DAS Kelara terdapat areal persawahan dengan luasan total 4.876,95 ha $(17,3 \%)$ selanjutnya dapat dilihat pada Tabel 2.

Tabel 2. Sebaran Jenis Penggunaan Lahan Di Hulu DAS Kelara

\begin{tabular}{llrr}
\hline No. & \multicolumn{1}{c}{ Jenis Penggunaan Lahan } & Luas (ha) & Persentase (\%) \\
\hline 1. & Hutan Lahan Kering Sekunder & $5.862,84$ & 20,8 \\
\hline 2. & Hutan Tanaman & 736,51 & 2,61 \\
\hline 3. & Pemukiman & 466,35 & 1,66 \\
\hline 4. & Perkebunan & $11.569,99$ & 41,05 \\
\hline 5. & Pertanian Lahan Kering & $4.641,27$ & 16,47 \\
\hline 6. & Sawah & $4.876,95$ & 17,3 \\
\hline 7. & Tubuh Air & 31,76 & 0,11 \\
\hline & $\quad$ Grand Total & $28.185,68$ & 100,00
\end{tabular}

Jenis penggunaan lahan pada Tabel 2 memperlihatkan sebaran terluas pada perkebunan dengan luasan $11.569,99$ ha $(41,05 \%)$ menyusul hutan lahan kering sekunder dengan luas $5.862,85$ ha atau $20,8 \%$. Pertanian lahan kering dan sawah menempati urutan terakhir. Hasil serupa menurut Limbong (2015) penggunaan lahan perkebunan pada tahun 2014 seluas 11.569,99 ha. Gambar 2.

Sebaran penggunaan lahan hasil interpretasi citra di Hulu DAS Kelara dapat dilihat pada 


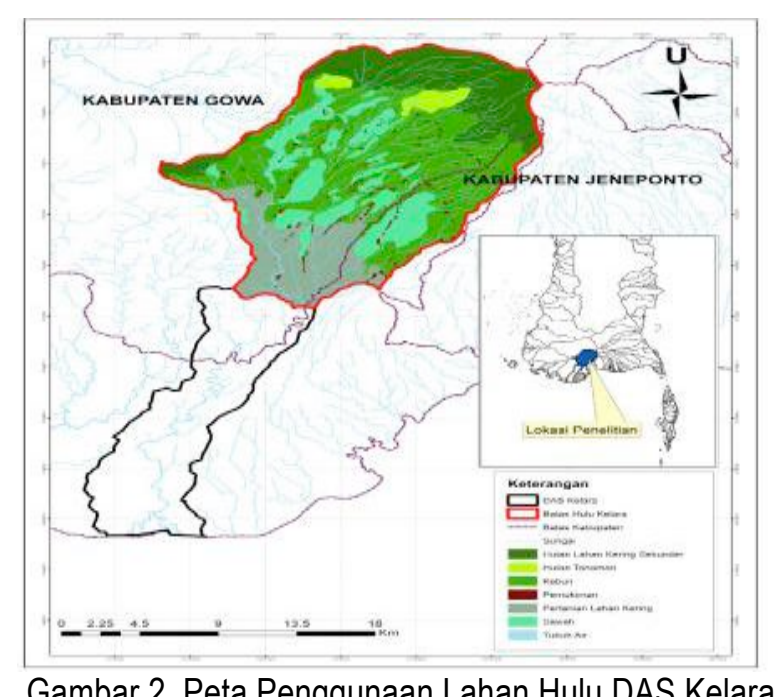

Hasil klasifikasi penggunaan lahan pada tahun 2014 kemudian dilakukan uji ketelitian hasil klasifikasi. Uji ketelitian dilakukan untuk mengetahui persentase tingkat kepercayaan dari hasil interpretasi citra landsat 8 berdasarkan tabel confusion matriks. Data dalam uji ketelitian ini adalah berupa titik-titik sampel yang telah ditetapkan dan dibandingkan dengan hasil pengamatan lapangan. Tabel confusion matriks klasifikasi penutupan tahun 2014 dapat dilihat pada Tabel 3.

Tabel 3. Confusion matriks titik sampel klasifikasi penutupan lahan tahun 2014 Hulu DAS Kelara

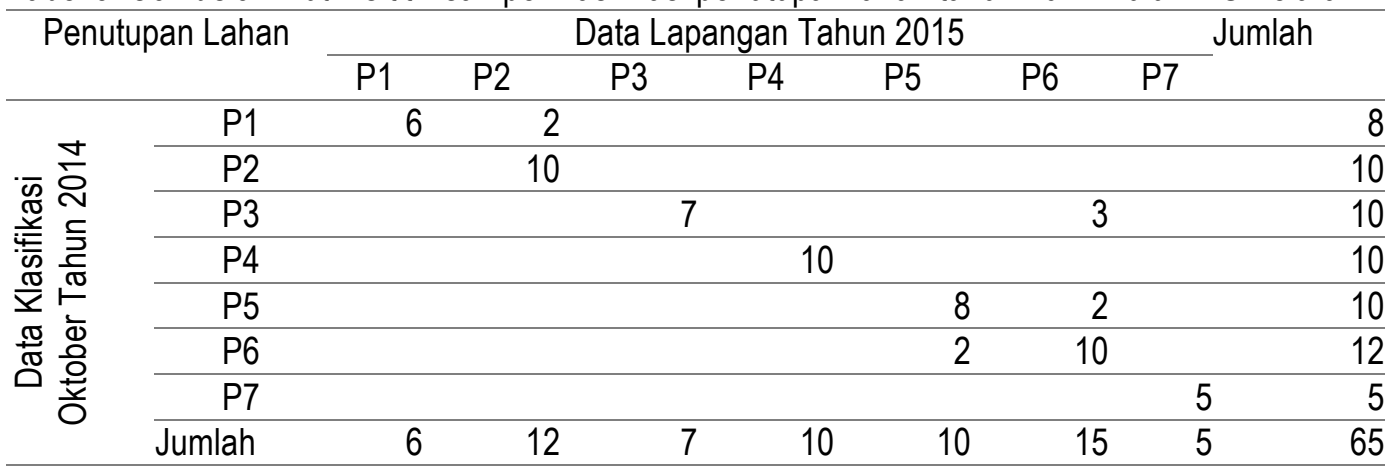

Keterangan :

P1 = Hutan Lahan Kering Sekunder

$\mathrm{P} 5=$ Sawah

P2 = Hutan Tanaman

$\mathrm{P} 3=$ Perkebunan

P6 $=$ Pertanian Lahan Kering

P4 = Pemukiman

P7 = Tubuh Air

Klasifikasi penutupan lahan 2014 pada Tabel 3 confusion matriks menunjukkan 56 titik sesuai antara titik sampel dan keadaan dilapangan, sedangkan 9 titik yang tidak sesuai. Dengan melihat tingkat ketelitian interpretasi yang dilakukan yaitu $86,2 \%$. Maka hasil interpretasi citra yang dilakukan dapat diterima sesuai dengan Lillesand and Kiefer (1997). 


\section{b. Persentase kesesuaian penggunaan lahan}

Persentase kesesuaian penggunaan lahan diketahui dari hasil overlay peta penutupan lahan dengan peta rencana pola ruang. Dari hasil overlay ini dapat diketahui luas dan persentasenya seperti yang tertera pada Tabel 4.

Tabel 4. Persentase Kesesuaian Penggunaan Lahan di Hulu DAS Kelara

\begin{tabular}{rrrr}
\hline No. & KesesuaianPenggunaan Lahan & Luas (ha) & Persentase (\%) \\
\hline 1. & Sesuai & $11.128,53$ & 39,48 \\
\hline 2. & Tidak Sesuai & $17.057,15$ & 60,52 \\
\hline & Total & $28.185,68$ & 100 \\
\hline
\end{tabular}

Penggunaan lahan berdasarkan Tabel 4 dapat diketahui bahwa penggunaan lahan yang sesuai dengan rencana pola ruang sebesar $11.128,53$ ha dan penggunaan lahan yang tidak sesuai sebesar $17.057,15$ ha.

Hasil wawancara terhadap 20 tokoh masyarakat diketahui bahwa perencanaan pola ruang belum tersosialisasikan dengan baik. Semua responden menjawab sama yaitu mereka belum pernah mendengar dan membaca tentang pola ruang di Hulu DAS Kelara sehingga dengan leluasa berusaha tani di dalam Kawasan Hutan. Demikian halnya juga dengan sosialisasi dari kegiatan instansi pemerintah utamanya penyuluhan ataupun sosialisasi tentang batas kawasan sehingga gangguan pada kawasan hutan lindung selain dari penebangan secara ilegal, perambahan untuk pertanian dan perkebunan pun terjadi. Berdasarkan persentase kesesuaian penggunaan lahan sebesar $60,52 \%$ yang tidak sesuai hal ini berdasarkan hasil wawancara penggunaan lahan yang mereka lakukan pada umumnya orang tua mereka dahulu tidak mengetahui kalau lahan yang mereka gunakan adalah kawasan hutan dan sekarang mereka sudah tinggal dan hidup bergantung pada hutan.

\subsection{Penentuan Arahan Penggunaan Lahan}

Setelah mengetahui penggunaan lahan di Hulu DAS Kelara ditemukan penggunaan lahan yang tidak sesuai sehingga akan dikembalikan ke pola ruang yang telah ditetapkan. Namun, apabila relokasi tidak mungkin untuk dilakukan maka upaya yang dapat dilakukan dengan melakukan arahan penggunaan lahan.

Pada Hulu DAS Kelara, arahan penggunaan lahan dilakukan pola HKm (Hutan Kemasyarakatan) dengan sistem agroforestry. Berdasarkan Permenhut No.P.88/Menhut-I/2014 pasal 6 Tentang Hutan Kemasyarakatan bahwa kawasan hutan yang dapat ditetapkan sebagai areal kerja HKm adalah kawasan hutan lindung dan kawasan hutan produksi.

Pada kasawan hutan lindung dan kawasan hutan produksi didalamnya sudah terdapat tanaman/penggunaan lahan oleh masyarakat secara intensif. Pada umumnya, di dalam kawasan lindung tidak diperbolehkan ada kegiatan budidaya yang berlangsung secara intensif. Keberadaan hutan tanaman, pertanian lahan kering, perkebunan dan sawah dalam kawasan hutan lindung merupakan indikator terjadinya perambahan. Untuk itu perlu penanganan yang sungguh-sungguh untuk menyelesaikan masalah ini.

Pada Kawasan Lindung terdapat Penggunaan lahan sawah ini merupakan kegiatan budidaya intensif yang dilakukan oleh masyarakat yang sebenarnya pada hutan lindung tidak diperbolehkan adanya kegiatan budidaya yang dilakukan secara intensif sehingga akan dilakukan arahan penggunaan lahan yang cocok. Maka arahan penggunaan lahan yang cocok yaitu pola intensifikasi yang dimaksudkan areal sawah yang sudah ada dimaksimalkan produksinya dengan luas lahan yang mereka kuasai sehingga tidak terjadi perluasan lahan (ekstensifikasi).

Arahan penggunaan lahan berupa pola HKm (hutan kemasyarakatan) bertujuan untuk meningkatkan kesejahteraan masyarakat setempat melalui pemanfaatan sumberdaya hutan secara optimal, adil dan berkelanjutan (Permenhut No.P.88/Menhut-II/2014). Untuk HKm yang dikembangkan dihutan produksi, jenis tanaman utamanya adalah jenis pohon hutan (penghasil kayu) dan bisa dicampur dengan pohon buah-buahan dan atau jenis pohon serbaguna (penghasil buah/pangan) dengan proporsi 
2:1 (67\% kayu dan 33\% buah atau pohon serbaguna). HKm dikembangkan dikawasan hutan lindung maka jenis tanaman utamanya adalah yang hasil utamanya bukan kayu agar tanaman/pohon tersebut tidak ditebang, misalnya jenis-jenis shorea penghasil tengkawang, durian, kemiri, dll, jenis-jenis ini dapat dicampur dengan jenis penghasil kayu dengan proporsi 2:1 (67\% pohon serbaguna dan $33 \%$ pohon kayu) (Murniati dan Sumarhani, 2010).

Pada areal kawasan budidaya, arahan penggunaan lahan yaitu sistem agroforestry. Agroforestry adalah suatu sistem pengelolaan lahan secara intensif dengan mengkombinasikan tanaman kehutanan dan tanaman pertanian dengan maksud agar diperoleh hasil yang maksimal dari kegiatan pengelolaan hutan tersebut dengan tidak mengesampingkan aspek konservasi lahan serta budidaya praktis masyarakat lokal (Anggreani, I dan Wibowo, A, 2007 dalam Guntara, 2013).

Pada penggunaan lahan sawah, kebun dan pertanian lahan kering dapat dilakukan dengan sistem agroforestry yaitu suatu penanaman tanaman kehutanan dipadukan dengan tanaman pertanian dengan pengaturan ruang untuk tanaman kehutanan ditanam di pematang atau di pinggiran/batas lahan milik petani. Untuk penggunaan lahan kebun dengan pola tumpang sari antara tanaman musiman berupa kopi (Coffea arabika) atau coklat (Theobrama cacao) dan tanaman tahunan berupa pohon tahunan yaitu sengon. Sedangkan, pertanian lahan kering di arahkan untuk menanam tanaman tahunan berupa jati (Tectona grandis) sebagai batas lahan milik petani.

Dengan diterapkannya pola tanam agroforestry dapat memperoleh dua keuntungan sekaligus yaitu produksi (ekonomi) dan ekologi seperti yang di nyatakan oleh Suprayogo (2003) dalam Rianti dan Winarto (2013) bahwa "Sistem agroforestry dapat menggantikan fungsi ekosistem hutan sebagai pengatur siklus hara dan pengaruh positif terhadap lingkungan lainnya dan di sisi lain dapat memberikan keluaran hasil yang diberikan dalam sistem pertanian tanaman semusim. Dapat dilihat pada Gambar 3 peta arahan penggunaan lahan dan Lampiran 1.

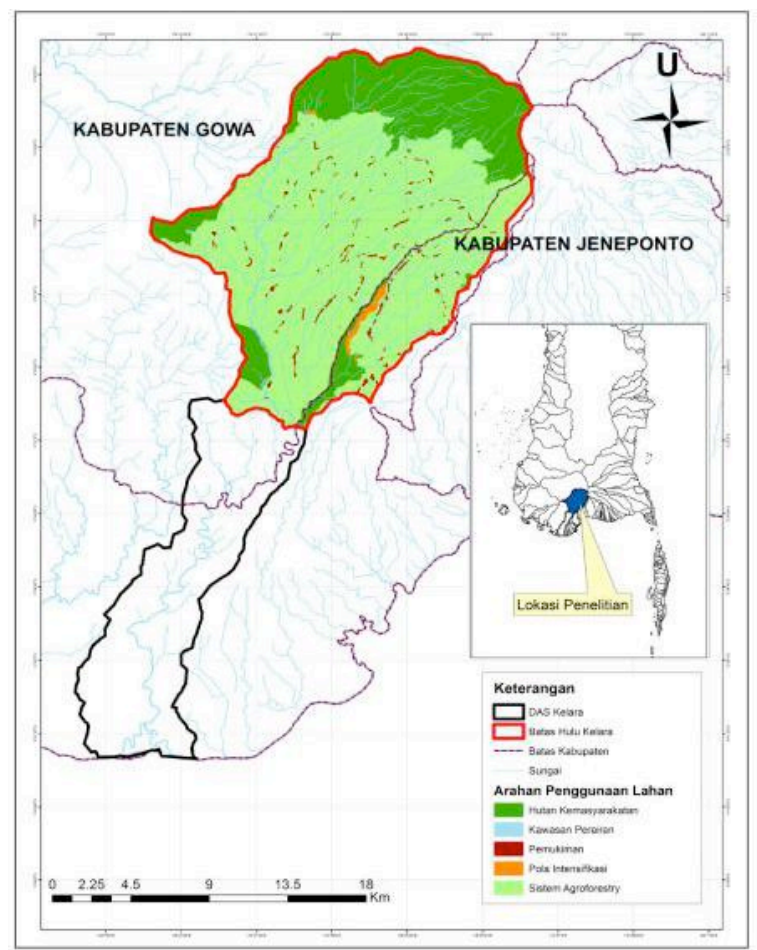

Gambar 3. Peta Arahan Penggunaan Lahan 


\section{KESIMPULAN}

Berdasarkan hasil penelitian yang diperoleh maka dapat ditarik kesimpulan bahwa (i) terjadi ketidaksesuaian antara penggunaan lahan dengan rencana pola ruang wilayah pada hutan lindung, hutan produksi dan hutan konservasi, dan (ii) arahan penggunaan/pengelolaan lahan yaitu hutan kemasyarakatan $(\mathrm{HKm})$ dengan sistem agroforestry, Pola Agroforestry dan Pola Intensifikasi.

\section{DAFTAR PUSTAKA}

As-syakur, A.R dan Adnyana, I.W.S. (2009). Analisis Indeks Vegetasi Menggunakan Citra ALOS/AVNIR-2 dan Sistem Informasi Geografis (SIG) untuk Evaluasi Tata Ruang Kota Denpasar. Jurnal Bumi Lestari, Volume 9 No.1, Februari 2009, hlm. 1-11.

Ferdinan, F., Jamilah dan Sarifuddin. (2013) .Evaluasi Kesesuaian Lahan Sawah Beririgasi di Desa Air Hitam Kecamatan Lima Puluh Kabupaten Batubara. Jurnal Online Agroekoteknologi, Vol 1 , No. 2, Maret 2013.

Guntara. (2013). Agroforestry Sebagai Alternatif Pemanfaatan Lahan Bawah Tegakan untuk Peningkatan Pendapatan Petani di Kabupaten Lumajang. Penyuluh Kehutanan Dinas Kehutanan Kabupaten Lumajang.

Lillesand, T.M., dan R.W. Kiefer. (1994). Penginderaan Jauh dan Interpretasi Citra. Gadjah Mada University Press. Yogyakarta.

Limbong, A. (2015). Perencanan Penggunaan Lahan untuk Mitigasi Erosi di Hulu Daerah Aliran Sungai Kelara. Fakultas Kehutanan Universitas Hasanuddin. Makassar. [Tidak dipublikasikan]

Murniati dan Sumarhani. (2010). Social Forestry Menuju Restorasi Pembangunan Kehutanan Berkelanjutan. Pusat Penelitian dan Pengembangan Perubahan Iklim dan Kebijakan. Bogor.

Peraturan Menteri Kehutanan Republik Indonesia Nomor : P.61/Menhut-II/2014 Tentang Monitoring dan Evaluasi Pengelolaan Daerah Aliran Sungai. Jakarta.

Peraturan Menteri Kehutanan Republik Indonesia Nomor : P-88/Menhut-I//2014 Tentang Hutan Kemasyarakatan. Jakarta.

Pradana, B., Sudarsono,B dan Subiyanto, S. (2013). Analisis Kesesuaian Lahan Pertanian Terhadap Komoditas Pertanian Kabupaten Cilacap. Jurnal Geodesi Undip Volume 2, Nomor 2, Tahun 2013, (ISSN:2337-845X).

Rianti, I.P dan Winarto, V. (2013). Ada yang berbeda dengan Agroforestry Suksesi Alami Berkelanjutan. http://bp2sdmk.dephut.go.id. Diakses pada tanggal 23 Februari 2016 pukul 11.38 Wita.

Syaifuddin, D. dan Anwar, I. (2008). Kajian Potensi Lahan Untuk Menunjang Optimalisasi Pengembangan Tanaman Jagung di Kabupaten Gowa dan Takalar. Jurnal Agrisistem, Juni 2008, Vol.4 No.1.

Udkhiyah. (2013). Perencanaan Jalur Interpretasi "The Gate of Secret" dalam Mengangkut Identitas Cirebon Sebagai Kota Wisata Budaya. UniversitasPendidikan Indonesia. Repository.upi.edu.

Undang-Undang Republik Indonesia Nomor 41 Tahun 1999 Tentang Kehutanan. Jakarta.

Zamroh, M. R. A. (2014). Analisis Perubahan Penggunaan Lahan Untuk Permukiman dikecamatan Kaliwangu dengan Sistem Informasi Geografis. Jurnal IImiah Pendidikan Geografis Vol.2 No.1 Oktober 2014. 